\title{
Empirical Analysis of Demand for Real Money Balances in Africa: Panel Evidence from Nigeria and Ghana
}

\author{
Chigozie Nelson Nkalu \\ Lecturer, Department of Economics, University of Nigeria, \\ Nsukka Enugu State, Nigeria \\ PhD Candidate, Department of Economics, Aberdeen Business School, \\ University of Aberdeen, Scotland, UK \\ nelson.nkalu@unn.edu.ng;nkaluconnection@gmail.com; \\ c.nkalu.2o@abdn.ac.uk
}

\begin{abstract}
This study investigates demand for real money balances in Africa using panel timeseries data from Nigeria and Ghana between 1970 and 2014. The study employs Levin, Lin, Chu common unit root process and Pedroni Residual Cointegration Test which the results reveal that all the variables in the model are stationary and cointegrated respectively. Data sourced from the World Development Indicators (WDI) were analyzed using Panel Two-Stage Estimated Generalized Least Squares (cross-section Seemingly Unrelated Regression model (SURE)) with Instrumental Variables (IV). The results conform to the liquidity preference theory, with all the variables - inflation, real interest rates, and official exchange rates are statistically significant except real income. It is recommended that the monetary authorities in Africa especially the economies of Nigeria and Ghana should adopt appropriate monetary policies by placing interest rates, inflation and official exchange rates at acceptable levels to boost income through private sector investments.
\end{abstract}

\section{Keywords}

Real Money Balances - Panel EGLS - interest rates - inflation - real income - Africa Nigeria - Ghana - JEL: E12, E41, E51, E6o 
The discussion on the demand for real money balances in Africa has been on the forefront of monetary economics and literature. Money demand function acts as a stabilization policy which depends on the ability of Central Bank to adjust money supply to its demand in order to avoid monetary disturbances from inhibiting real output (Nduka, Chukwu \& Onuzuruike, 2013). If the money demand function is unstable and undergoes substantial unpredictable shifts, as Keynes thought, then velocity is unpredictable, and the quantity of money may not be tightly linked to aggregate spending, as it is in the modern quantity theory (Mishkin, 2007). A good understanding of the stability and determinants of the demand for real money balances forms the core in the conduct of monetary policy as it enables a policy-driven change in monetary aggregates to have predicable influences on output, interest rate, and ultimately price (Sriram, 1999).

Literally, demand for money means the desire to hold money in cash rather than in liquid assets. Theoretically, in his liquidity preference theory of money demand, Keynes (1936) noted that transactions, precautionary and speculative motives are the rationale behind money demand by individuals in the society, that is, having income as a sole determinant of money demand: $M d=f(Y)$, where Md is money demand and income is denoted by Y. In transections motive for money demand, people hold money as a medium of exchange which hinges literally on current income, but not necessarily on interest rates; precautionary motive for holding money depends on uncertainties and need for unexpected expenditures, and thus speculative motive sees money demand as alternatives for holding money in terms of portfolios with uncertain returns (Jagdish, 2009). Therefore, summing up the three motives for money demand amount to real money balances which is mathematically depicted as $M^{d} / P=f(Y)$, where $M^{d} / P$ stands for the real money balances, and $\mathrm{P}$ is the price. Generally, the Keynesian liquidity preference theory states that the demand for real money balances is a function of income and interest rates, (Mishkin, 2007).

The choice of this study which brought the economies of Nigeria and Ghana into focal point for empirical investigation is formed by a number of reasons. Besides the obvious reason that both economies share similarities in political and economic structures, the economies have experienced very large fluctuations in the government budget deficits and high accumulation of foreign debt, poor export performance, huge service account deficits, external debt amortization, low inflow of foreign direct investment, misappropriation of external funding support, excessive domestic monetary and credit expansion; 


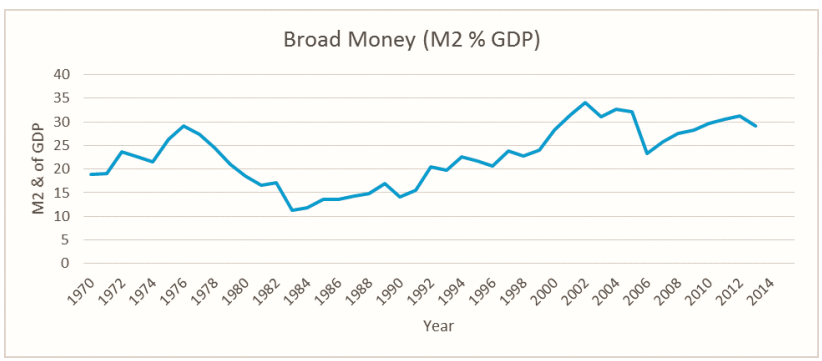

FIGURE 1.1 Trends of Broad Money (M2) in Ghana (1970-2014) SOURCE: RESEARCHER'S COMPUTATIONS WITH DATA FROM WORLD DEV. INDICATORS (WDI) (2014)

price distortions and a deterioration in the terms of trade (Ogiogio, 1996; Obioma,1998; \& Nkalu, 2015).

In Ghana, available statistics from World Development Indicators (2014) equally reveals that the money demand (M2) hovers at $14.1 \%$ and $29.1 \%$ between 1970 and 1990. However, between 1991 and 2006, M2 hovers at a range of $15.6 \%$ and $34.1 \%$, after which it experiences a sharp drop in 2006 at $23.3 \%$. In 2007, M2 picks up at 25.7\% and continue rising at a steady rates up to $29.1 \%$ in 2013 where it starts dropping.

The major policy objectives of the monetary authorities of Nigerian and Ghanaian economies are to control inflation to a single digit, as well as maintaining a relatively lower interest rate to encourage money demand for capital investments which can have positive consequences on economic growth. The Nigerian and Ghanaian governments through their respective Central Banks does alter monetary aggregates to achieve these policy objectives. The specification of an appropriate money demand function is vital in determining the optimum quantity of money to be supplied in an economy. Effective monetary policy implicitly assumes a stable money demand function.

In the figure 1.3 and 1.4 above, the discrepancies among M2, inflation and real interest rate can be clearly seen. For example, in figure 1.3, as M2 increases on a steady rate from $10.97 \%$ to $31.51 \%$ between 1970 and 1986 , inflation hovers between $13.8 \%$ and $5.7 \%$, while real interest rate falls within the rage of $-29.2 \%$ and $10.7 \%$ respectively. As M2 experiences slight decline between 1987 and 2002 at a range of $25.8 \%$ and $21.9 \%$, inflation becomes highly unstable at a peak of $72.8 \%$ in 1995, while real interest rate hovers in both negative and positive directions hitting its negative peak of $-10.3 \%$ in 1995 and positive peak of $24.3 \%$ in 1998. Also, between 2000 and 2014, evidences are bound where a fluctuations in money demand does not commensurate with a relative changes in 


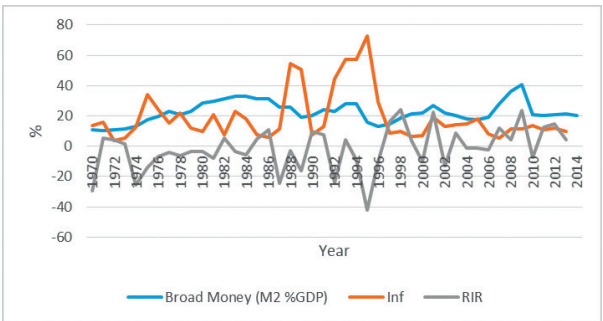

FIGURE 1.2 Chart Showing the Interactions of Broad Money (M2), Real Interest Rate (RIR) and Inflation in Nigeria (1970-2014)

SOURCE: RESEARCHER'S COMPUTATIONS USING DATA FROM WORLD DEV. INDICATORS (WDI) (2014)

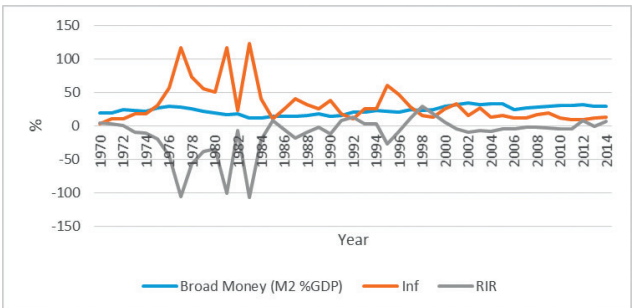

FIGURE 1.3 Chart Showing the Interactions of Broad Money (M2), Real Interest Rate (RIR) and Inflation in Ghana (1970-2014) SOURCE: RESEARCHER'S COMPUTATIONS USING DATA FROM WORLD DEV. INDICATORS (WDI) (2014)

inflation and low interest rates. In figure 1.4; also, the same evidences are bound where $\mathrm{M} 2$, inflation and real interest rate are not in conformity with the standard Keynes's liquidity preference theory for both economies. Furthermore, M2 of Ghana in 2013 stood at $29.1 \%$ with $11.6 \%$ inflation rate and negative real interest rate of about $1.4 \%$. However, if the relationship is not stable, money supply targeting might not be an effective policy option for controlling inflation as well as setting interest rates to a reasonably level. 
In line with the objectives of the World Bank and International Monetary Fund sponsored Structural Adjustment Program (SAP), Nigeria introduced SAP in 1986 and Ghana launched its version of SAP as Economic Recovery Program (ERP) in 1983. The later evaluations of the program in the two economies reveals that Ghana recorded remarkable achievements in comparison with Nigeria (World Bank, 1989). The policy quintupled the broad money between 1986 and 1992 through increase in credit to public sector in Nigeria with deregulation of both interest rates and exchange rate (World Bank, 1994).

Based on the foregoing, this empirical study seeks to investigate amongst other objectives the effect and magnitude of income on the real money balances in Africa while holding Nigeria and Ghana as a benchmark. The study equally try to identify if the demand for real money balances in Africa is stable or unstable while using Nigeria and Ghana as a focal points. As part of the study, this analysis also seeks to ascertain the role inflation, exchange rate and interest rates play in the demand for real money balances in Africa by adopting the case of Nigeria and Ghana. However, the Seamingly Unrelated Regression (SURE) model with instrumental variables (IV) as well as Panel Estimated generalized least square (EGLS) will be adopted in carrying out the study, while employing panel data from Nigeria and Ghana.

\section{$2 \quad$ Review of Literature}

\subsection{Empirical Literature}

Apere and Karimo (2014) examine the demand for real money balances in Nigeria over the period 1971 to 2012 using the partial adjustment model. The study show that the transaction and precautionary motives for holding money, and the speculative motive are all important determinants of real money demand in Nigeria in the short run. The partial adjustment coefficient indicates that 4.1 percent of the discrepancy between desired and actual real money demanded is eliminated each year in the short run. Furthermore, in the steady state, after the adjustment process is complete, when the desired and actual money demanded are equal it is only the speculative motive that is an important driver of the demand for real money balances. The estimated money demand function is stable, indicating the absence of structural breaks in the demand for real money balances in Nigeria. The overall model is statistically significant and robust to serial correlation, even at the lag five (5). The study therefore conclude that in the short-run both real income and interest rates are important determinants of real money balances in Nigeria but it is 
interest rate that is important in the long-run, which therefore suggests the need to distinguish between short- and long-run monetary policy targets.

Havi, Enu and Opoku (2014) examine the demand for broad money and its long run stability in Ghana using multivariate time series approach between 1970 and 2011. The Johansen cointegration test reveals that the variables are stationary and cointegrated, therefore, vector error correction model, VECM is used to determine the factors that influence real money aggregate in Ghana. It is concluded that nominal foreign interest rate and expected inflation are significant determinants of real money aggregate in the long run while real income and nominal exchange rate are significant determinant of real money aggregate in the short run. The plots of cumulative sum of recursive residuals (CUSUM) and cumulative sum of recursive residuals squares (CUSUMSQ) tests show that money demand function is stable over the period.

Doguwa, Olowofeso, Uyaebo, Adamu, and Bada (2014) estimate the money demand function in Nigeria in the aftermath of the recent global financial crisis and examine whether its underlying properties has changed over the years. Specifically, the result from the velocity test shows that there exist a stable long-run demand for money function during the period 1991:Q1- 2013:Q4, while accounting for the possibility of structural breaks is investigated. The Gregory- Hansen residual based test for cointegration detected both intercept and regime shifts in 2007:Q1 as the null of no cointegration is rejected at 1 percent significance level, indicating that long run relationship exists between real money supply, real income, real monetary policy rate, exchange rate spread and movements in exchange rate in Nigeria. This estimation technique is robust to structural break, which ensures that the estimated parameters are unbiased. The CUSUMSQ test provides evidence of a stable money demand function before and after the crisis. The study infers that since the relationship among the variables holds over a fairly long period of time, the estimated money demand model provides important foundations for monetary policy setting in Nigeria.

Aiyedogbon (2013) empirically examines money demand function (M2) in Nigeria using time series annual data ranging from 1986 to 2010 . The variables of the study are real money demand function, gross capital formation, interest rate, inflation rate, exchange rate, government expenditure and openness of the economy. The study adopts vector error correction model (VECM) and cointegration test to examine if there exist short and/or long run relationship exists among the variables in the model respectively. The study also uses cumulative sum of recursive residuals (CUSUM) and cumulative sum of recursive residuals squares (CUSUMSQ) to test for the stability of the money demand function. However, the empirical findings of the cointegration test shows that 
a long run equilibrium relationship exist among the variables in the model. In the long run, the study also discovers that interest rate, inflation and openness of the economy have negative impacts on money demand while the gross capital formation, exchange rate and government expenditure on the other hand, have a positive impact on money demand in Nigeria. The result from the vector error correction model (VECM) equally reveals that the lag values of money demand, gross capital formation, interest rate and exchange rate have a negative relationship with current money demand in the short run, with inflation and openness of economy indicating a positive relationship. The test of stability result shows that real money demand function in Nigeria is stable as neither the CUSUM nor the CUSUMSQ plots cross the 5 percent critical boundaries.

Iyoboyi and Pedro (2013) examine the demand for money in Nigeria: evidence from bounds testing approach using small time series sample size covering from 1970 to 2010. The studies apply the autoregressive distributed lag bounds test approach and cointegration test to determine the characteristics of the time series used in the study. Also adopted in the study are the augmented Dickey-Fuller (ADF) and Philips-Perron (PP) unit root tests to ascertain the stationarity of the variables in the model. The empirical results indicate cointegration relations among narrow money demand, real income, short term interest rate (STIR), real expected exchange rate (REER), expected inflation rate (EIR), and foreign real interest rate (FRIR) in the period under investigation. However, the results further reveal that real income and interest rate are significant variables explaining the demand for narrow money in Nigeria, although real income is a more significant factor in both the short and long term.

Bassey, Bessong and Effiong (2012) investigate the effect of monetary policy on demand for money in Nigeria using annual time series data spinning from 1970 to 2007. The study utilizes Ordinary Least Multiple regression statistical technique in testing for the relationship between interest rate and demand for money, inflation rate and demand for money and exchange rate and demand for money. The result of the finding reveals that there exist an inverse relationship between interest rate and money demanded, there exist and inverse relationship between expected inflation rate and money demanded and there exist an inverse relation between exchange rate and money demanded in Nigeria.

Bitrus (2011) studies the demand for money in Nigeria using annual time series spanning 26 years on both narrow ( $\mathrm{M} 1)$ and broad money (M2), income, interest rate, exchange rate and the stock market. The study employs the use of multiple regression analysis, the unit-root test for stationarity and CUSUM stability test. The study reveals that money demand function is stable in Nigeria for the sample period and that income is the most significant determinant of 
the demand for money. The result also gathers that stock market variables can improve the performance of money demand function in Nigeria.

Dagher and Kovanen (2011) adopt the bounds testing procedure developed by Pesaran, Shin and Smith (2001) to test the stability of the long-run money demand for Ghana using quarterly data between 1990Q1-2009Q4. The study incorporate broad money, real income, and interest and exchange rate into the model. The results provide strong evidence for the presence of a stable, wellidentified long-run money demand during a period of substantial changes in the financial markets. The empirical evidence points to complex dynamics between money demand and its determinants while suggesting that deviations from the equilibrium are rather short-lived.

Bitrus (2011) examines the determinants of the demand for money in developed and developing countries using a comparative analysis of the effectiveness of the determinants of the demand for money in both developing and developed countries. The study reveals that income related factors or the scale variables are more effective in the developing countries while factors that work through the financial system are more effective in the developed economies and that stock market variables should not be ignored in modeling demand for money even in emerging economies since they constitute an alternative to holding cash. Also, the level of the development of a country's financial system determines which factors will be relevant targets in moping excess liquidity within an economy.

\section{3}

\section{Data and Method of Analysis}

The data for this study were mainly sources from the World Development Indicators (2014) ranging from 1970 to 2014. The demand for real money balances was derived by taking the ratio of money demand (M2) to Consumer Price Index (CPI) proxy for price level. To account for the variables that affect demand for real money balances in Nigeria and Ghana, Panel Two-Stage Estimated Generalized Least Squares (cross-section Seemingly Unrelated Regression model (SUR)) with Instrumental Variables (IV) was adopted after testing for the stationarity of the panel time-series data using Levin, Lin, Chu (2002) unit root test approach. This test is known as the "heterogeneous panel unit root test". The Levin, Lin, Chu test arises from separate ADF regression for each cross section (country) member:

$$
\Delta Y_{I, T}=a_{i}+Y_{i, t-i}+\sum_{j=1}^{P_{i}} \beta_{i, j} \Delta_{i, t-j}+\varepsilon_{i, t}
$$


where: series $Y_{i, t}(i=1,2, \ldots, N ; t=1,2, \ldots, T)$ is the time series for panel member (country/region) I over period, pi is the number of lags in the ADF regression, and the error term $\left(\varepsilon_{i, t}\right)$ are assumed to be independently and identically different (IDD) $\left(o, \sigma_{i}^{2}\right)$ for all I and t. Both $\gamma_{i}$ and the lag order $\beta_{i, j}$ in equation (3.4) are allowed to vary across section (countries). IPS relaxes the assumption of homogeneity of the coefficient(s) of the lagged dependent variable. It appraises the null hypothesis that each time series in the panel has a unit root (i.e its first differences are stationary) for all cross-section units against the alternative hypothesis that at least one of the series is stationary.

$$
H_{O}: \gamma_{i}=O \text { is tested against the alternative } H_{A}: \gamma_{i}=\gamma_{i}<0 \text { for all } i \ldots
$$

The study equally employed Pedroni (2004) panel cointegration to test for testing for the existence of cointegration. The Pedroni (2004) panel cointegration is applied to the following time- series panel regression framework:

$$
\begin{aligned}
& Y_{i, t}=\alpha_{i}+\sum_{j=1}^{P t} \beta_{j i} X_{j i t}+\varepsilon_{i t} \\
& \varepsilon_{i t}=\rho_{i} \varepsilon_{i(t-1)}+W_{i t}
\end{aligned}
$$

where: $Y_{i t}$ and $X_{j i t}$ are the observed variables; $\varepsilon_{i t}$ represents the disturbance term from the panel regression; $\alpha_{i}$ allows for the possibility of country-specific effects to the coefficients $\left(\beta_{\mathrm{ji}}\right)$ allow for variation across individual countries. The null hypothesis of no cointegration of the pooled (within-dimension) is:

$$
H_{O}: \rho_{i}=1 \text { for all I against } H_{1}: \rho_{i}=\rho<1
$$

Under the first hypothesis, the within-dimensional estimation assumes a common value for $\rho(=\rho)$. In brief, this procedure excludes any additional source of heterogeneity as between individual country members of the panel. The null hypothesis of no cointegration of the pooled (between-dimension) estimation is specified as:

$$
\mathrm{H}_{\mathrm{O}}: \rho_{\mathrm{i}}=1 \text { for all I against } \mathrm{H}_{\mathrm{o}}: \rho_{\mathrm{i}}<1
$$

Under the alternative hypothesis, the between-dimensional estimation does not assume a common value for $p_{i}=p$. Thus, it allows for an additional source of possible heterogeneity across individual country members of the panel. Pedroni suggested two types of tests to determine the existence of heterogeneity of the cointegration vector. First, the test uses the within-dimension 
approach (i.e. panel test). It uses four statistics that are panel v-statistic, panel $\rho$-statistic, panel PP-statistic and the panel ADF-statistic. These statistics pool the autoregressive coefficients across different panel members for the unit root tests to be performed on the estimated residuals. Second, the test is based on between-dimensional approaches (group test). It includes three statistics: a group $\rho$-statistic, a group PP-statistic and the individually-estimated autoregressive coefficients for each panel member (Pradhan, Arvin, Samadhan and Taneja, 2013).

The empirical model of this study postulates an open economy money demand function which relates the demand for real money balances as a function of real income, interest rates, inflation rate and expected exchange rate depreciation, and thus we adopted the following model: Mathematically, the functional relationship of the variables in the model can be stated thus:

$$
\left.\mathrm{M}_{2}^{\mathrm{d} / \mathrm{P}}\right)=f(\mathrm{RGDP}, \mathrm{RIR}, \mathrm{INF}, \mathrm{OER})
$$

The mathematical equation (1.7) can be expressed econometrically as shown in equation (1.8) below:

$$
\left(\mathrm{M}_{2}^{\mathrm{d}} / \mathrm{P}\right)_{\mathrm{it}}=\beta \mathrm{O}+\beta_{1} \mathrm{RGDP}_{\mathrm{it}}+\beta_{2} \mathrm{RIR}_{\mathrm{it}}+\beta_{3} \mathrm{INF}_{\mathrm{it}}+\beta_{4} \mathrm{OER}_{\mathrm{it}}+\varepsilon_{\mathrm{it}}
$$

Taking the logarithm of the equation (1.8) yields equation (1.9) as shown below:

$$
\operatorname{In}\left(M_{2}{ }^{d} / P\right)_{i t}=\beta_{o}+\beta_{1} R_{G D P} i t+\beta_{2} R I R_{i t}+\beta_{3} I N F_{i t}+\beta_{4} O E R_{i t}+\varepsilon_{i t}
$$

where: In = natural logarithm, $\mathrm{M}_{2}{ }^{\mathrm{d}}=$ demand for broad (M2) money, $\mathrm{P}=$ domestic price level proxied by Consumer Price Index $(\mathrm{CPI}), \mathrm{M}_{2} \mathrm{~d} / \mathrm{P}=$ demand for real broad $\left(\mathrm{M}_{2}\right)$ money balances, $\mathrm{RGDP}=$ real gross domestic product proxy of real income, RIR $=$ real interest rate, $\mathrm{INF}=$ inflation rate, $\mathrm{OER}=$ official exchange rate, $\varepsilon=$ white noise disturbances term, $\mathrm{t}=$ time trend, $\mathrm{i}=$ cross-sectional unit 1 for Nigeria, 2 for Ghana, $\beta s=$ constant term and parameters. The justification of the model is based on the necessity to understand the link between demand for real money balances and its determinants in Nigeria and Ghana.

\section{Results and Discussion}

The empirical results for the demand for real money balances in Africa evidenced from Nigerian and Ghanaian data is presented in table 1 below after satisfying the pre-tests process of non-stationarity and cointegrating conditions 
TABLE 1 Panel two-stage EgLS (cross-section SUR) result Dependent Variable: LOG(RealM2)

\begin{tabular}{lccrc}
\hline Variable & Coefficient & Std. Error & t-Statistic & Prob. \\
\hline Constant & 2.514387 & 0.452482 & 5.556873 & 0.0000 \\
RGDP & $2.95 \mathrm{E}-14$ & $1.91 \mathrm{E}-14$ & 1.543469 & 0.1264 \\
RIR & -0.036480 & 0.012688 & -2.875106 & 0.0051 \\
INF & -0.027808 & 0.010853 & -2.562160 & 0.0122 \\
OER & -0.032714 & 0.004669 & -7.005880 & 0.0000 \\
\hline
\end{tabular}

Total Panel Observations $=90$

$\mathrm{R}^{2}$ : 0.57

Adjusted $\mathrm{R}^{2}: 0.55$

SOURCE: COMPUTED USING EVIEWS VERSION 8 STATISTICAL SOFTWARE

of the variables in the model using Levin, Lin, Chu common unit root approach and Pedroni Residual Cointegration Test respectively.

From the Table 1 above, as expected, all the variables showed the right signs with inflation (INF), real interest rates (RIR) and official exchange rates (OER) being negative, and income (RGDP) being positive. All things being equal, the income elasticity of 2.95 percent indicates that if real income, $\mathrm{RGDP}_{\text {it }}$ increases by 1 percent the quantity of money people would want to hold (real money balance) increases by 1.54 percent. This is because as real income increases the purchasing power of individuals also increases. Furthermore, a percentage increase in interest rate reduces money balances by 0.036 percent. This is as a result of interest rates increasing the risks to invest in bonds, this in turn means higher returns to investment and so people will prefer investing in assets and bond to holding excess cash balances. Similarly, a percentage increase in inflation (INF) and official exchange rates (OER) will as well decrease money balances by 0.028 and 0.033 respectively.

Inflation, real interest rates and official exchange rates are statistically significant at 5 percent levels of significant. This indicates that real interest rate, inflation and official exchange rates are important determinants of real money demand in Africa especially in Nigeria and Ghana. Conversely, real income is not statistically determinant but shows positive relationship with real money balances. And this could be attributable to income inequalities, distribution and disparities among individual countries in Africa especially in Nigeria and Ghana. The $\mathrm{R}^{2}$ of 0.57 is moderately high but this should be taken with a grain of salt because contemporaneous error terms across countries. 
The major conclusion that can be drawn from this study is that inflation, interest rates and exchange rates are all important determinants of demand for real money balances indicating that the speculative motive drives the demand for real money balances in Africa especially in the economies of Nigeria and Ghana more than the transactions and precautionary motives. It is evidenced from the estimated results that income as proxied by RGDP has a positive relationship with the demand for real money balances, but does not sufficiently influence the demand for real money balances in Africa with Nigeria and Ghana as a reference economies. This therefore conforms to the liquidity preference theory. In showing a negative relationship between interest rates, official exchange rates, inflation and the demand for real money balances, this study is similar to that of Bassey, et al (2012). However, findings from this study are more robust since it covers more than 45 observations for each individual countries which is the benchmark for satisfying the central limit theorem of large sample size. The study is also robust to serial correlation and endogeneity bias as a result of the Instrumental Variables (IV) employed in the estimation. These characteristics make this study similar to that of Aiyedogbon (2013) and Doguwa, et al (2014). Finally, this study recommends that the monetary authorities in Africa especially in Nigeria and Ghana should adopt appropriate monetary policies by placing interest rates, inflation and official exchange rates at acceptable limits to boost income through private sector investment.

Based on the recommendations, some policy implications can be drawn. Fiscal authorities in African economies especially Nigeria and Ghana should adopt contractionary fiscal policies such as increasing of taxes and decreasing of government expenditures to control inflationary pressures which shall invariably lower the level of disposable income of the tax payers to reduce household consumptions and thus boost investments.

\section{References}

Aiyedogbon, J. O., (2013). Empirical Analysis of Money Demand Function in Nigeria: 1986-2010. International Journal of Humanities and Social Science, 3(8), 132-146.

Apere, T. O., \& Karimo, T. M. (2014). The Demand for Real Money Balances in Nigeria: Evidence from a Partial Adjustment Model. European Journal of Business, Economics and Accountancy, 2(2), 1-14. 
Bassey, B. E., Bessong, P. K, \& Effiong, C., (2012). The Effect of Monetary Policy on Demand for Money in Nigeria. Interdisciplinary Journal of Contemporary Research in Business, 4(7), 430-435.

Bitrus, Y. P., (2011). The demand for money in Nigeria. European Journal of Business and Management, 3(6), 63-70.

Bitrus, Y. P., (2011). The determinants of the demand for money in developed and developing countries. Journal of Economics and International Finance, 3(15), 1-9.

Doguwa, S. I., Olowofeso, O. E., Uyaebo, S. O. U., Adamu, I., \& Bada, A. S. (2014). Structural Breaks, Cointegration and Demand for Money in Nigeria. CBN Journal of Applied Statistics, 5(1), 1-19.

Havi, E. D. K., Enu, P., \& Opoku, C. D. K. (2014). Demand for Money and Long run Stability in Ghana: Cointegration Approach. European Scientific Journal, 10(13), 1-15. Iyoboyi, M., \& Pedro, L. M., (2013). The Demand for Money in Nigeria: Evidence from Bounds Testing Approach. Business and Economics Journal, 1(1), 1-10.

Jagdish, H. (2009). Monetary Economics (2nd Ed.). Canada: Routledge.

Keynes, J. M. (1936). The general theory of employment, interest and money. London: Macmillan.

Levin, A., Lin, C. F., \& Chu, C.S. J. (2002). Unit root tests in panel data: Asymptotic and finite-sample properties. Journal of Econometrics, 108, 1-24.

Mishkin, F. S. (2007). The Economics of Money, Banking, and Financial Markets (8th Ed.). Boston: Person Education, Inc. 499-500.

Nduka, E. K., Chukwu, J. O. and Nwakaire, O. N. (2013). Stability of Demand for Money in Nigeria. Asian Journal of Business and Economics, 3(3.4): 1-11.

Nkalu, C. N., (2015). The Effects of Budget Deficits on Selected Macroeconomic Variables in Nigeria and Ghana (1970-2013). Asian Journal of Empirical Research, 5(10), 133-146.

Obioma, E. C. (1998). Balance of Payments and Exchange Rate Management in Nigeria: Empirical Evidence from the Monetary Approach. NCEMA Policy Analysis Series. $4(2)$.

Ogiogio, G. O. (1996). Exchange Rate Policy, Trade Policy Reform and the Balance of Payments". In Obadan, M. I. and M. A. Iyoha (Ed.). Macroeconomic Policy Analysis: Tools, Techniques and Applications to Nigeria. National Center for Economic Management and Administration. 45-51.

Padroni, P. (2004). Panel Cointegration: Asymptotic and Finite Sample Properties of Pooled Time Series Tests with an Application to the PPP Hypothesis. Econometric Theory, 20, 597-625

Sriram, S. S. (2009) "The Gambia: Demand for Broad Money and Implications for Monetary Policy Conduct", Im F Working Paper, African Department, International Monetary Fund. 33-46. 
World Bank (1989). Ghana - Structural adjustment for growth. Washington, DC: World Bank. Retrieved from: http://documents.worldbank.org/curated/en/49640 1468249898352/Ghana-Structural-adjustment-for-growth.

World Bank (1994). Nigeria - Structural adjustment program: policies, implementation, and impact. Washington, DC: World Bank. Retrieved from: http://documents .worldbank.org/curated/en/959o91468775569769/Nigeria-Structural-adjustment -program-policies-implementation-and-impact. 